New Age: A Guide 



\title{
New Age
}

\section{A Guide}

\author{
Alternative Spiritualities from \\ Aquarian Conspiracy to Next Age
}

\author{
DAREN KeMP
}

Edinburgh University Press 


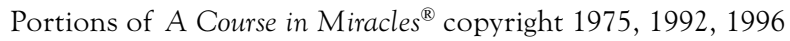
reprinted by permission of the Foundation for A Course in Miracles, Inc. ${ }^{\circledR}$ (www.facim.org). All rights reserved. A Course in Miracles $^{\circledR}$ is a registered trademark of the Foundation for A Course in Miracles ${ }^{\circledR}$. The ideas represented herein are the personal interpretation and understanding of the author and are not necessarily endorsed by the copyright holder of A Course in Miracles ${ }^{\circledR}$.

Granqvist, Pehr and Berit Hagekull (2001), Journal for the Scientific Study of Religion, 40.3: 541-2 reprinted by permission of the Society for the Scientific Study of Religion.

Ivakhiv, Adrian J. (2001), Claiming Sacred Ground: Pilgrims and Politics at Glastonbury and Sedona, Indiana University Press p. 40, reprinted by permission of Indiana University Press.

Kemp, Daren (2000), 'A Platonic delusion: the identification of psychosis and mysticism', Mental Health, Religion and Culture, 3.2: 162, reprinted by permission of Taylor and Francis, www.tandf.co.uk.

Lynch, Frederick (1977), American Behavioral Scientist 20.6: 895, copyright (C) Sage Publications, Inc, reprinted by permission of Sage Publications, Inc.

(C) Daren Kemp, 2004

Transferred to Digital Print 2011

Edinburgh University Press Ltd

22 George Square, Edinburgh

Typeset in Goudy Old Style by J\&L Composition, Filey, North Yorkshire

Printed and bound in Great Britain by

CPI Antony Rowe, Chippenham and Eastbourne

A CIP record for this book is available from the British Library

ISBN 0748615318 (hardback)

ISBN 0748615326 (paperback)

The right of Daren Kemp to be identified as author of this work has been asserted in accordance with the Copyright, Designs and Patents Act 1988. 